\title{
COMPARISON OF SALIVARY PH BEFORE AND AFTER CONSUMING A SOLUTION OF SUGAR AND PALM SUGAR IN DENTISTRY FACULTY'S STUDENT OF ANDALAS UNIVERSITY
}

\author{
Risa Widia ${ }^{1}$, Nila Kasuma ${ }^{2}$ \\ ${ }^{1}$ Faculty of Dentistry Andalas University \\ ${ }^{2}$ Departemen of Oral Biology Faculty of Dentistry Andalas University
}

\begin{abstract}
Sugar ( sucrose) is a carbohydrate compound which is soluble in water and directly absorbed by the body to convert into energy. Diet sugar ( sucrose) can affect the pH of saliva, where the compounds have fermented in the mouth which produces acid to lower the $\mathrm{pH}$ of saliva and the results of this activity will initiate the process of demineralization of tooth structure. The palm sugar contains sucrose higher at $84 \%$ compared with $20 \%$ of sugar cane. ${ }^{8}$ The purpose of this study was to determine differences in comparison the $\mathrm{pH}$ of saliva before and after consuming a solution of sugar and palm sugar. This study was an experimental study using pre-test and post-test design. The samples used as many as 26 people. Each sample was given treatment consumes sugar and palm sugar solution. Salivary pH measurements using dental saliva $\mathrm{pH}$ indicator. Analysis of data using the Wilcoxon test. The result show an average difference in the $\mathrm{pH}$ of saliva after consuming a solution of sugar of $0.57 \pm 0.32$ while the average difference in the $p H$ of saliva after consuming palm sugar solution at $0.67 \pm 0.40$. The value of $p>0.05$ so there is no significant difference. Based on the research that has been done, it can be concluded that consuming a solution of sugar and palm sugar solutions together can decrease the $\mathrm{pH}$ of saliva.
\end{abstract}

Keywords : salivary $\mathrm{pH}$, sugar solution, palm sugar solution

Affiliasi penulis: ${ }^{1}$ Faculty of Dentistry Andalas

University

Korespondensi: Risa Widia

Email: risawidia5812@gmail.com

\section{PENDAHULUAN}

Salah satu cara untuk menentukan atau mengukur derajat asam atau basa saliva yaitu dengan $\mathrm{pH}$ (potensial of hydrogen). Derajat keasaman $\mathrm{pH}$ dan kapasitas buffer saliva ditentukan oleh susunan kualitatif dan kuantitaif elektrolit dalam saliva yang ditentukan oleh susunan bikarbonat, karena susunan bikarbonat sangat konstan dalam saliva dan berasal dari kelenjar saliva. ${ }^{1}$

Derajat keasaman saliva dalam keadaan normal antara 5,6 sampai 7,0 dengan rata-rata $\mathrm{pH}$ 6,7. Derajat keasaman $(\mathrm{pH})$ saliva optimum untuk pertumbuhan bakteri 6,5 sampai 7,5 dan apabila rongga mulut $\mathrm{pH}$-nya rendah antara 4,5 sampai 5,5 akan memudahkan pertumbuhan kuman asidogenik seperti Streptococus mutans dan Lactobacillus. ${ }^{2}$

Derajat asam $(\mathrm{pH})$ dan kapasitas bufer saliva dipengaruhi oleh beberapa faktor diantaranya yaitu irama siang dan malam, diet, perangsangan kecepatan sekresi, pasien hemodialisis, obat-obatan seperti antihistamin dan antidepresan, terapi radiasi pada kepala dan leher serta kondisi hormonal misalnya menstruasi, hamil, menopause.,3

pH saliva dan kapasitas bufer tinggi segera setelah bangun (keadaan istirahat) tetapi kemudian cepat turun dan tinggi seperempat jam setelah makan (stimulasi mekanik) tetapi biasanya turun 
lagi dalam waktu 30-60 menit dan agak naik sampai malam tetapi setelah itu turun. $^{3}$

Diet mempengaruhi kapasitas buffer saliva. Diet kaya sayuran dan diet kaya protein dapat menaikkan $\mathrm{pH}$ saliva sedangkan diet kaya karbohidrat dapat menurunkan kapasitas buffer saliva dan menaikkan metabolisme produksi asam oleh bakteri-bakteri dalam mulut.,

\section{Makanan atau minuman yang} dikonsumsi dapat menyebabkan saliva menjadi asam maupun basa. Sukrosa dan glukosa pada makanan dapat diragikan oleh bakteri rongga mulut dan membentuk asam sehingga $\mathrm{pH}$ plak menjadi turun sampai di bawah 5 dalam waktu 1-3 menit. Penurunan $\mathrm{pH}$ yang berulang dalam waktu tertentu mengakibatkan permukaan gigi rentan dan poses karies pun dimulai. Untuk kembali ke pH normal sekitar 7, dibutuhkan waktu sekitar 30-60 menit. ${ }^{5}$

Gula adalah suatu senyawa karbohidrat yang dapat larut dalam air dan langsung diserap tubuh untuk diubah menjadi energi. ${ }^{6}$ Gula merupakan komoditas penting bagi masyarakat Indonesia bahkan bagi masyarakat dunia. Gula sangat bermanfaat sebagai sumber kalori bagi masyarakat. ${ }^{7}$

Gula mempunyai bentuk, aroma, dan fungsi berbeda. Ada gula pasir yang merupakan gula tebu yang mengalami proses kristalisasi dan gula aren yang merupakan hasil olahan dari nira aren. Gula aren ini terdiri dari berbagai bentuk yaitu gula cetak dan gula semut. Gula cetak umumnya berbentuk sesuai dengan cetakannya sedangkan gula semut merupakan gula aren dalam bentuk kristal atau bubuk. Penggunaan dari gula semut ini lebih praktis karena mudah larut dan bisa dijadikan pengganti gula pasir. ${ }^{8,9}$

Gula bubuk aren mengandung sukrosa lebih tinggi yaitu $84 \%$ dibandingkan gula tebu yaitu $20 \%$. Sukrosa merupakan karbohidrat yang erat kaitannya dengan proses karies karena dimetabolisme cepat untuk menghasilkan zat asam oleh kuman asidogenik. Sukrosa yang tinggi dapat menyebabkan kadar kalsium menjadi rendah yang dapat menimbulkan gangguan pada gigi dan tulang. $8,9,10$

Gula pasir merupakan salah satu pemanis yang umum dikonsumsi masyarakat. Gula ini biasanya digunakan sebagai pemanis makanan maupun minuman, selain itu gula juga digunakan sebagai stabilizer dan pengawet yang memiliki indeks glikemik sebesar 58 sedangkan gula aren memiliki indeks glikemik yang sangat rendah yaitu 35 yang artinya produksi glukosa berlangsung lambat sehingga pankreas 
tidak perlu bekerja keras lagi dan pada beberapa penderita diabetes terbukti dapat menurunkan kadar gula darahnya setelah mengkonsumsi gula aren. Dengan indeks glikemik yang rendah itu membuat glukosa terbentuk secara perlahan yang berarti energi yang tercipta secara perlahan pula sehingga tubuh bugar lebih lama. ${ }^{8,11}$

Penelitian yang dilakukan oleh Yuke Yulianingsih (1990) terhadap gula pasir dan gula aren yang diberikan pada makanan tikus jenis wistar menunjukkan bahwa adanya perbedaan antara pengaruh gula pasir dengan gula aren terhadap aktifitas karies gigi dan pengaruh gula aren lebih besar daripada gula pasir. Hal ini ditinjau dari aspek kandungan sukrosa, $\mathrm{pH}$, serat, dan flour. Pengaruh kandungan sukrosa pada gula aren terhadap aktifitas karies gigi lebih besar daripada gula pasir. Dilihat dari test $\mathrm{pH}$ saliva, pengaruh gula aren lebih besar daripada gula pasir terhadap aktifitas karies gigi dimana $\mathrm{pH}$ tikus wistar setelah memakan gula aren lebih rendah daripada setelah memakan gula pasir. Serat gula aren lebih banyak daripada gula pasir. Serat yang tinggi dalam makanan merupakan hal yang baik untuk perlindungan gigi terhadap terjadinya karies gigi karena adanya sifat self cleansing dari serat tersebut. Seharusnya karena adanya serat yang lebih banyak, pangaruh gula aren lebih kecil daripada gula pasir namun mungkin ada faktor lain yang mempengaruhi ini. Kandungan flour pada gula pasir lebih tinggi daripada gula aren. Kandungan flour yang tinggi pada gula pasir dapat menghambat proses karies gigi dengan cara menghambat pembentukan asam oleh mikroorganisme.

Penelitian awal telah dilakukan di Laboratorium Biokimia Fakultas Kedokteran Universitas Andalas terhadap gula pasir dan gula aren semut menunjukkan bahwa $\mathrm{pH}$ gula pasir lebih tinggi daripada gula aren semut yaitu $\mathrm{pH}$ gula pasir sebesar 5,8 sedangkan $\mathrm{pH}$ gula aren semut sebesar 5,2. Kondisi ini menunjukkan bahwa $\mathrm{pH}$ gula aren lebih asam daripada gula pasir. Hal ini akan tidak menguntungkan bagi derajat keasaman saliva rongga mulut pada individu yang mengkonsumsi kedua gula tersebut secara berlebihan karena makanan atau minuman yang bersifat asam akan cenderung menurunkan $\mathrm{pH}$ saliva dan bersifat asam pula.

Menurut American Heart Foundation, sebaiknya perempuan tidak mengkonsumsi lebih dari 100 kalori tambahan dari gula perhari dan laki-laki 150 kalori perharinya. Artinya, untuk perempuan konsumsi gulanya tidak lebih dari 25 gram per hari dan 37,5 gram 
untuk laki-laki. Jumlah itu sudah mencakup gula di minuman, makanan, kudapan, permen, dan semua yang dikonsumsi pada hari itu. ${ }^{6}$

Menurut Riskesdas 2013, mengkonsumsi makanan atau minuman yang manis merupakan perilaku mengkonsumsi makanan berisiko. Perilaku konsumsi makanan berisiko dikelompokkan "sering" apabila penduduk mengkonsumsi makanan tersebut satu kali atau lebih setiap hari. Proporsi penduduk $\geq 10$ tahun konsumsi makanan dan minuman manis $\geq 1$ kali dalam sehari secara nasional adalah $53,1 \%$.

Menurut Pola Pangan Harapan, idealnya konsumsi gula pasir 9,9 $\mathrm{kg} / \mathrm{kap} /$ tahun dan konsumsi gula merah $1,1 \mathrm{~kg} / \mathrm{kap} / \mathrm{tahun}^{12}$ Menurut Hasil Survei Sosial Ekonomi Nasional Tahun 20092013, penduduk Indonesia pada tahun 2013 mengkonsumsi gula pasir sebanyak 6,6482 kg/kap/tahun dan mengkonsumsi gula merah sebanyak 0,5475 $\mathrm{kg} / \mathrm{kap} / \mathrm{tahun}$.

\section{Kementerian}

Kesehatan

(Kemenkes) Indonesia mencatat 4,8 persen penduduk Indonesia mengkonsumsi gula lebih 50 gram/orang per hari. Kepala Badan Penelitian dan Pengembangan Kesehatan (Balitbangkes) Kemenkes Tjandra Yoga Aditama mengatakan, Data hasil penelitian Suvei Diit Total Balitbangkes tahun 2014 yang baru selesai diolah tahun ini menunjukkan bahwa 4,8 persen penduduk Indonesia mengkonsumsi gula lebih 50 gram per orang per hari. ${ }^{13}$

Jadi, terdapat hubungan antara gula dan kesehatan rongga mulut. Diet gula dan karbohidrat lainnya dapat mempengaruhi $\mathrm{pH}$ saliva. Gula dan karbohidrat yang dapat difermentasi lainnya setelah dihidrolisasi maka dapat menghasilkan substrat untuk aktivitas bakteri rongga mulut yang dapat menurunkan $\mathrm{pH}$ saliva dan hasil dari aktivitas ini akan mengawali proses demineralisasi struktur gigi sehingga dapat menyebabkan karies. ${ }^{4,14}$

Berdasarkan uraian tersebut, peneliti tertarik untuk meneliti perbandingan $\mathrm{pH}$ saliva sebelum dan sesudah mengkonsumsi gula pasir dan gula aren pada mahasiswa Fakultas Kedokteran Gigi Universitas Andalas. Penelitian ini akan dilakukan secara langsung atau mengkonsumsi larutran gula pasir dan gula aren. Selanjutnya dilakukan pengukuran $\mathrm{pH}$ saliva setelah mengkonsumsi kedua jenis gula tersebut.

\section{METODE}

Penelitian ini merupakan penelitian eksperimental menggunakan metode pendekatan pre-test and post-test 
design yang dilaksanakan di ruang SkillsLab Fakultas Kedokteran Gigi Universitas Andalas pada Desember 2015 - Maret 2016. Bahan yang digunakan dalam penelitian ini adalah Larutan gula pasir dengan konsentrasi 20 gram gula pasir dilarutkan dalam $100 \mathrm{ml}$ air. Larutan gula aren dengan konsentrasi 20 gram gula aren dilarutkan dalam $100 \mathrm{ml}$

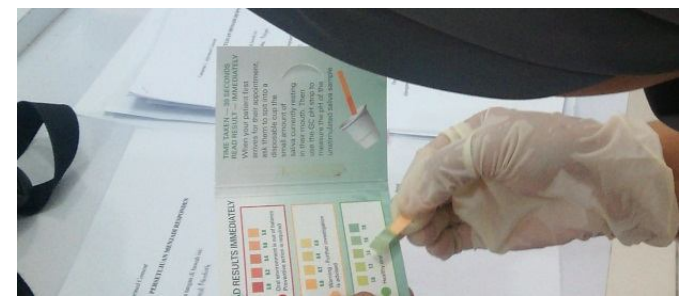
air, Dental saliva $\mathrm{pH}$ indicator, Stopwatch, dan Wadah pengumpulan saliva.

Pada hari 1 mengumpulkan subjek sesuai kriteria inklusi dan ekslusi. Pada langkah ini dilakukan pemeriksaan $\mathrm{OHI}$ terhadap populasi yang akan dijadikan sampel penelitian untuk mendapatkan kriteria inklusi yang mempunyai OHI baik, lalu dilakukan pengundian secara acak. Lalu sampel mengisi inform consent.

Pada hari 2 dan 3 dilakukan pengukuran $\mathrm{pH}$ saliva sebelum dan sesudah mengkonsumsi larutan gula pasir dan gula aren dengan Dental Saliva $p H$ Indicator dengan pengumpulan salivanya menggunakan metode spitting. Membandingkan $\mathrm{pH}$ saliva sesudah mengkonsumsi larutan gula pasir dengan $\mathrm{pH}$ saliva sesudah mengkonsumsi larutan gula aren. Analisis data menggunakan uji Wilcoxon. 
Tabel 1. $\mathrm{pH}$ saliva sebelum mengkonsumsi larutan gula pasir dan gula aren

\begin{tabular}{llllll}
\hline $\begin{array}{c}\text { Jenis } \\
\text { Gula }\end{array}$ & pH Saliva & $\mathrm{n}$ & $\bar{X} \pm \mathrm{SD}$ & Min & Maks \\
\hline $\begin{array}{c}\text { Gula } \\
\text { Pasir }\end{array}$ & Sebelum & 26 & $7,39 \pm 0,39$ & 6,6 & 7,8 \\
& & & & & \\
Gula & Sebelum & 26 & $7,39 \pm 0,34$ & 6,6 & 7,8 \\
Aren & & & & &
\end{tabular}

|Tabel 2. pH saliva sesudah mengkonsumsi larutan gula pasir dan gula aren

\begin{tabular}{cccccc}
\hline $\begin{array}{c}\text { Jenis } \\
\text { Gula }\end{array}$ & pH Saliva & $\mathrm{n}$ & $\bar{X} \pm \mathrm{SD}$ & Min & Maks \\
\hline $\begin{array}{c}\text { Gula } \\
\text { Pasir }\end{array}$ & Sesudah & 26 & $6,82 \pm 0,54$ & 5,8 & 7,6 \\
$\begin{array}{c}\text { Gula } \\
\text { Aren }\end{array}$ & Sesudah & 26 & $6,72 \pm 0,55$ & 5,8 & 7,6 \\
\hline
\end{tabular}

Tabel 3. Perbandingan rata-rata selisih $\mathrm{pH}$ saliva sesudah mengkonsumsi larutan gula pasir dan gula aren

\begin{tabular}{cccc}
\hline Kelompok & $\mathrm{n}$ & $\bar{X} \pm \mathrm{SD}$ & $\mathrm{p}$ \\
\hline Gula Pasir & 26 & $0,57 \pm 0,32$ & 0,128 \\
Gula Aren & 26 & $0,67 \pm 0,40$ & \\
\hline
\end{tabular}

Hasil yang diperoleh dari Tabel 3 menunjukkan bahwa selisih rata-rata $\mathrm{pH}$ saliva sesudah mengkonsumsi larutan gula pasir dari 26 subjek adalah 0,57 dengan standar deviasi 0,32 . Selisih ratarata $\mathrm{pH}$ saliva sesudah mengkonsumsi larutan gula aren dari 26 subjek adalah 0,67 dengan standar deviasi 0,40. Hasil uji Wilcoxon menunjukkan nilai $\mathrm{p}=0,128$ sehingga didapatkan nilai $\mathrm{p}>0,05$, maka dapat disimpulkan tidak terdapat perbedaan yang bermakna dari selisih rata-rata $\mathrm{pH}$ saliva sesudah konsumsi larutan gula pasir dan gula aren secara statistik.

\section{PEMBAHASAN}

Penelitian ini dilakukan untuk mengetahui perbedaan perbandingan $\mathrm{pH}$ sebelum dan sesudah mengkonsumsi larutan gula pasir dan gula aren pada mahasiswa angkatan 2012 dan 2015 Fakultas Kedokteran Gigi Universitas Andalas. Perbandingan $\mathrm{pH}$ saliva diamati sebelum dan sesudah mengkonsumsi kedua larutan gula tersebut. Untuk mengetahui perbandingan $\mathrm{pH}$ saliva tersebut dilakukan pengukuran $\mathrm{pH}$ saliva dengan menggunakan dental saliva $p H$ indicator.

Pada kondisi normal tanpa stimulasi, pH saliva berada diantara 6,77,4. $\mathrm{pH}$ kritis saliva yang dapat mempengaruhi keseimbangan mineral saliva berkisar antara 5,5-6,5. Kondisi pH saliva dalam kondisi kritis dapat menyebabkan demineralisasi email gigi. ${ }^{23}$

Makanan dan minuman yang kaya dengan karbohidrat menyebabkan $\mathrm{pH}$ saliva turun (asam). Salah satu jenis karbohidrat adalah gula (sukrosa) yang mudah difermentasi oleh bakteri dan merangsang bakteri untuk menghasilkan asam, ${ }^{32}$ juga merupakan media terbaik untuk berkembangnya bakteri Streptococcus mutans yang menjadi penyebab karies gigi. ${ }^{2,3}$ 
Hasil penelitian yang telah dilakukan pada 26 mahasiswa angkatan 2012 dan 2015 Fakultas Kedokteran Gigi Universitas Andalas diperoleh rerata $\mathrm{pH}$ saliva sebelum mengkonsumsi larutan gula pasir sebesar $7,39 \pm 0,39$ dan rerata pH saliva sebelum mengkonsumsi larutan gula aren sebesar 7,39 $\pm 0,34$.

Hasil penelitian yang telah dilakukan pada 26 mahasiswa angkatan 2012 dan 2015 Fakultas Kedokteran Gigi Universitas Andalas yang diberikan perlakuan mengkonsumsi larutan gula pasir dan gula aren diperoleh rerata $\mathrm{pH}$ saliva sesudah mengkonsumsi larutan gula pasir sebesar 6,82 $\pm 0,54$ dan rerata $\mathrm{pH}$ saliva sesudah mengkonsumsi larutan gula aren sebesar 6,72 $\pm 0,55$. Penurunan $\mathrm{pH}$ saliva karena adanya stimulus meminum larutan gula dan karena gula adalah salah satu jenis karbohidrat yang menyebabkan $\mathrm{pH}$ saliva turun. ${ }^{2,3}$

Rata-rata $\mathrm{pH}$ saliva sesudah mengkonsumsi larutan gula aren lebih rendah daripada rata-rata $\mathrm{pH}$ saliva sesudah mengkonsumsi larutan gula pasir. Sesuai dengan penelitian yang dilakukan oleh Yuke Yulianingsih (1990) terhadap gula pasir dan gula aren yang diberikan pada makanan tikus jenis wistar menunjukkan bahwa adanya perbedaan antara pengaruh gula pasir dengan gula aren terhadap aktifitas karies gigi dan pengaruh gula aren lebih besar daripada gula pasir. pH tikus wistar setelah memakan gula aren lebih rendah daripada setelah memakan gula pasir.

Makanan atau minuman yang bersifat asam akan cenderung menurunkan $\mathrm{pH}$ saliva dan bersifat asam pula. Hal ini sesuai dengan penelitian awal yang telah dilakukan di Laboratorium Biokimia Fakultas Kedokteran Universitas Andalas terhadap gula pasir dan gula aren semut menunjukkan bahwa $\mathrm{pH}$ gula pasir sebesar 5,8 (asam) dan $\mathrm{pH}$ gula aren semut sebesar 5,2 (asam). Kondisi ini menunjukkan bahwa $\mathrm{pH}$ gula pasir dan $\mathrm{pH}$ gula aren sama-sama bersifat asam, hal ini akan tidak menguntungkan bagi derajat keasaman saliva rongga mulut pada individu yang mengkonsumsi kedua gula tersebut secara berlebihan yaitu untuk perempuan tidak lebih dari 25 gram per hari dan untuk laki-laki tidak lebih dari 37,5 gram per hari. Jumlah itu sudah mencakup gula di minuman, makanan, kudapan, permen, dan semua yang dikonsumsi pada hari itu. ${ }^{6}$

Rosa Novetty Hutagalung (2007) menyatakan bahwa terjadi perubahan bermakna $\mathrm{pH}$ saliva sesudah kumurkumur dengan larutan sukrosa, sorbitol, dan xylitol. Sesudah kumur-kumur dengan larutan sukrosa, $\mathrm{pH}$ saliva 
mengalami penurunan. Sesudah kumurkumur dengan larutan sorbitol, $\mathrm{pH}$ saliva dapat mengalami penurunan dan peningkatan sedangkan sesudah kumurkumur dengan larutan xylitol, $\mathrm{pH}$ saliva cenderung mengalami peningkatan. ${ }^{19}$

Nur Nubli Julian Parade (2011) menyatakan bahwa terdapat pengaruh pemberian minuman jeruk kemasan terhadap perubahan $\mathrm{pH}$ saliva yaitu terjadi penurunan $\mathrm{pH}$ saliva yang mana kelompok perlakuan pada menit ke-2 $(6,47 \pm 0,46)$ dengan $\mathrm{p}=0,000$, menit ke- 6 $(6,18 \pm 0,30)$ dengan $\mathrm{p}=0,005$, dan menit ke-10 $(6,66 \pm 0,27)$ dengan $p=0,000$ karena minuman jeruk kemasan tersebut bersifat asam dan mengandung karbohidrat total dan gula yang tinggi. ${ }^{33}$

Isha Goel dkk (2013) menyatakan bahwa penurunan $\mathrm{pH}$ saliva setelah mengkonsumsi jus buah lebih tinggi daripada mengkonsumsi minuman karbonat, $\mathrm{pH}$ saliva yang dihitung segera setelah mengkonsumsi minuman bikarbonat yaitu antara 3,21 sampai 6,86 dengan nilai rerata $5,47 \pm 0,78$ sedangkan $\mathrm{pH}$ saliva sesudah mengkonsumsi jus buah antara 3,26 sampai 6,53 dengan

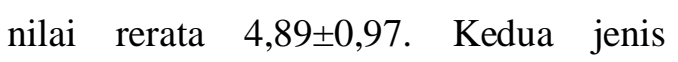
minuman itu menurunkan $\mathrm{pH}$ saliva karena minuman karbonat memiliki kandungan asam yang tinggi dan memiliki $\mathrm{pH}$ rendah dan jus buah mengandung gula yang tinggi. ${ }^{34}$

Berdasarkan hasil penelitian yang telah dilakukan pada 26 mahasiswa angkatan 2012 dan 2015 Fakultas Kedokteran Gigi Universitas Andalas menunjukkan bahwa rerata selisih $\mathrm{pH}$ saliva sesudah mengkonsumsi larutan gula pasir sebesar $0,57 \pm 0,32$ sedangkan rerata selisih $\mathrm{pH}$ saliva sesudah mengkonsumsi larutan gula aren sebesar $0,67 \pm 0,40$. Nilai $p>0,05$, maka dapat disimpulkan tidak terdapat perbedaan yang bermakna.

Hasil penelitian ini menunjukkan bahwa mengkonsumsi larutan gula pasir dan mengkonsumsi larutan gula aren sama-sama dapat menurunkan $\mathrm{pH}$ saliva tanpa ada perbedaan yang bermakna karena kedua jenis gula ini bersifat asam. Gula pasir memiliki kandungan sukrosa sekitar 20\% dan gula aren memiliki kandungan sukrosa sekitar $84 \%$. Sukrosa merupakan karbohidrat yang erat kaitannya dengan proses karies karena dimetabolisme cepat untuk menghasilkan zat asam oleh kuman asidogenik. Sukrosa yang tinggi dapat menyebabkan kadar kalsium menjadi rendah yang dapat menimbulkan gangguan pada gigi dan tulang. $8,9,10$

Gula pasir dan gula aren adalah disakarida yang merupakan gabungan 
monosakarida yang saling berikatan satu sama lain melalui kondensasi. Artinya telah terjadi perpindahan sebuah ion hidrogen dari salah satu monosakarida dan satu ion hidroksil dari monosakarida lainnya. Kedua monosakarida itu bergabung satu sama lainnya. Ion hidrogen dan ion hidroksil bergabung untuk membentuk air. Bila gula (sukrosa) ini dicerna, proses kondensasi dibalik maka gula diubah menjadi monosakarida. Enzim sukrase di dalam getah pencernaan pada traktus gastrointestinal memecah sukrosa menjadi senyawa monosakarida yaitu terdiri dari glukosa dan fruktosa yang siap diserap oleh tubuh. Proses ini yang disebut hidrolisis. Hasil dari proses hidrolisis adalah monosakarida yang merupakan pendonor ion $\mathrm{H}^{+}$sehingga saliva bersifat asam ( $\mathrm{pH}$ saliva turun). ${ }^{31}$

\section{KESIMPULAN}

Dari hasil penelitian yang telah dilakukan maka dapat disimpulkan tidak terdapat perbedaan yang bermakna perbandingan antara ph saliva sebelum dan sesudah mengkonsumsi larutan gula pasir dan gula aren.

\section{KEPUSTAKAAN}

1. Diana, et, al (2005). Peranan Sorbitol dalam Mempertahankan Kestabilan $\mathrm{pH}$ Saliva pada Proses Pencegahan Karies. Maj. Ked. Gigi, Vol.38.

2. Soesilo, Diana; Santoso, Rinna Erlyawati; Diyatri, Indeswati (2005). The Role of Sorbitol in Maintaining Saliva's $\mathrm{pH}$ to Prevent Caries Process. Dental Journal, Vol. 38, Hal. 25-28. Surabaya.
3. Amerongen, A. van Nieuw (1991). Ludah dan Kelenjar Ludah. Gadjah Mada University Press. Yogyakarta.

4. Hongini, Siti Yundali Dan Aditiawarman, Mac (2012). Kesehatan Gigi dan Mulut. Pustaka Reka Cipta. Bandung.

5. Kidd, E. A. M dan Bechal, S. J (2012). Dasar-Dasar Karies. Penyakit dan Penanggulangan. EGC. Jakarta

6. Darwin, Philips (2013). Menikmati Gula Tanpa Rasa Takut. Sinar Ilmu. Jakarta.

7. Dachliani, Diesy Meireni (2006). Permintaan Impor Gula Indonesia Tahun 1980- 2003. Tesis Universitas Diponegoro, Semarang.

8. Adli, Muhammad Zimamul (2010). Pemanfaatan Gula Bubuk Aren sebagai Bahan Pembuatan Permen Anti Diabetes. Bogor Agricultural University.

9. Lempang, Mody (2012). Pohon Aren dan Manfaat Produksinya. Info Teknis EBONI, Vol. 9, No. 1, Hal 37-54.

10. Khoswanto, Christian dan Soehardjo, Istiati (2005). Pengaruh Peningkatan Konsentrasi Sukrosa dalam Diet terhadap Kadar Kalsium Gigi Tikus Wistar. Dental Journal, Vol. 38, Hal:4-7.

11. Aritonang, Inriyani Sintia (2011). Gula Pasir versus Gula Aren. Fakultas MIPA Universitas Padjajaran.

12. Wahyuni, Sri dan Sinuraya, Forcina (2014). Agrarian Reform And Food Security. Standar Konsumsi Gula sebagai Dasar Neraca Gula.

13. Sulistyawati, Rr Laeny (2015). 4,8 Persen Penduduk Indonesia Konsumsi Gula Berlebih. Diakses Pada Tanggal 14 Desember 2015; http://www.republika.co.id

14. Vinita (2015). Efek Stevia (Stevia rebaudiana bertoni) Terhadap Perubahan $\mathrm{pH}$ dan Perkembangan Karies Pada Rongga Mulut Mencit. Undergraduate Thesis Universitas Kristen Maranatha.

15. Almeida, Patricia Del Vigna De, et al (2008). Saliva Composition and Functions: A Comprehensive Review. The Journal of Contemporary Dental Practice, Vol. 9, No. 3.

16. Kusumasari, Nila (2012). Pengaruh Larutan Kumur Ekstrak Siwak (Salvadora persica) terhadap $\mathrm{pH}$ Saliva. Karya Tulis Ilmiah Fakultas Kedokteran Universitas Diponegoro.

17. Sridianti (2015). Apakah Fungsi Kelenjar Ludah (Saliva). Diakses Pada Tanggal 08 Desember 2015;

Http://www.Sridianti.Com/ApakahFungsi-Kelenjar-Ludah Saliva.Html 
18. Alamsyah, Rika Mayasari (2010). Efek Perbedaan Cara Meminum Softdrink (Minuman Ringan) terhadap Penurunan pH Saliva pada Siswa SMP Raksana Medan. Fakultas Kedokteran Gigi USU, Medan.

19. Hutagalung, Rossa Novetty (2008). Perbandingan $\mathrm{pH}$ Saliva Sebelum dan Sesudah Kumur-Kumur dengan Larutan Sukrosa , Sorbitol, dan Xylitol pada Mahasiswa Fakultas Kedokteran Gigi USU. Skripsi Fakultas Kedokteran Gigi USU, Medan.

20. Houwink, B, et al (1992). Ilmu Kedokteran Gigi Pencegahan. Gadjah Mada University Press. Yogyakarta.

21. Stookey, George K (2008). The Effect of Saliva on Dental Caries. JADA, Vol. 139.

22. Afifah, Nur (2010). Uji Beda Pemberian Teh Hijau dan Teh Hitam terhadap Perubahan $\mathrm{pH}$ Saliva Secara In Vivo. Skripsi Fakultas Kedokteran Universitas Sebelas Maret, Surakarta.

23. Hervina (2014). Ekstrak Teh Hijau 3\% yang Dikumur Selama Tiga Menit Lebih Meningkatkan Sekresi, pH, dan Kadar Bikarbonat Saliva Dibanding Satu Menit dan Dua Menit. Tesis Universitas Udayana, Denpasar.

24. Puspasari, Dyna (2013). Pengaruh Pemakaian Pasta Gigi yang Mengandung Ekstrak Daun Sirih terhadap Perubahan $\mathrm{pH}$ Saliva dan Bleeding on Probing (Bop) pada Gingivitis Marginalis Kronis. Universitas Hasanudin.

25. Tarigan, Mega Citra (2012). Tinjauan Nata Dari Air Tebu (Nata De Sugar Cane) Dilihat dari Warna, Aroma, Rasa, dan Tekstur. Skripsi Fakultas Teknik Universitas Negeri Medan.

26. Sinaga, Dian Novita Sari (2010). Identifikasi Kesesuaian Lahan Tebu di PT Perkebunan Nusantara II Kebun Helvetia. Skripsi Fakultas Pertanian USU, Medan.

27. Trianita, Anggi (2014). Pengaruh Konsumsi Susu Kedelai Murni dan Susu Kedelai Kemasan Terhadap pH Saliva Mahasiswa FKG Unand. Skripsi Fakultas Kedokteran Gigi Unand.

28. Putri, Lollie Agustina P (2013). Respon Pertumbuhan Bibit Aren (Arenga pinata merr) terhadap Pemberian Pupuk Organik Cair. Fakultas Pertanian USU, Medan.

29. Pontoh, Julius (2012). Metode Analisa dan Komponen Kimia Dalam Nira dan Gula Aren. Prosiding Seminar Nasional Aren. Fakultas Matematika dan IPA Universitas Sam Ratulangi, Manado.
30. Dahlan, M. Sopiyudin (2013). Statistik untuk Kedokteran dan Kesehatan. Salemba Medika. Jakarta.

31. Guyton, Arthur C dan Hall, John E (2008). Buku Ajar Fisiologi Kedokteran. EGC. Jakarta.

32. Decker, Riva Touger and Loveren, Cor Van (2003). Sugars and Dental Caries. American Society for Clinical Nutrition, Vol. 78, Hal. 881S-891S.

33. Parade, Nur Nubli Julian (2011). Pengaruh konsumsi minuman jeruk kemasan terhadap perubahan $\mathrm{pH}$ saliva. Skripsi Fakultas Kedokteran Universitas Sebelas Maret, Surakarta.

34. Goel, Isha et, al (2013). Effects of Carbonated Drink and Fruit Juice on Salivary $\mathrm{pH}$ of Children. International Journal of Scientific Study, Vol. 01, Hal. 60-69. 